\title{
Kahoot-based learning game to improve mathematics learning motivation of elementary school students
}

\author{
Adi Setiawan $^{1}$, Soeharto ${ }^{1}$ \\ ${ }^{1}$ Yogyakarta State University, Indonesia \\ $\triangle$ adisetiawan.2017@student.uny.ac.id*
}

\section{Article Information \\ Submitted January 01, 2020 \\ Revised April 15, 2020 \\ Accepted April 24, 2020}

Keywords

Game-Based Learning;

Kahoot Mathematics;

Learning Motivation.

\begin{abstract}
Mathematics is an important lesson for elementary school students. However, mathematics is usually identified as difficult, unenjoyable and boring. Teachers need to motivate the students that mathematics can be fun. One media that could be used is Kahoot. This study aimed to apply Kahoot-based learning games to improve mathematics learning motivation for the fourth-grade elementary school students. This study is classroom action research (CAR). It was carried out in two learning cycles using the Kemmis \& Taggart model. The subjects of this study were the fourth-grade elementary school students in the second semester of the 2018/2019 academic year consisted of 28 students. The research data were obtained through interviews, mathematics learning achievement tests, learning observation sheets, and field notes. Data analysis was carried out qualitatively and supplemented by quantitative analysis. The results showed that students' mathematics learning motivation could be improved through Kahoot-based learning games. Students' test results showed an increase in learning motivation by 19.85 or $44.55 \%$. The results of this study provide information for teachers, schools, and researchers to improve students' learning motivation through Kahoot-based learning game.
\end{abstract}

\section{INTRODUCTION}

Mathematics is one of the lessons in elementary schools. It is identified as difficult and unpleasant lessons for students. Students are afraid, unmotivated, and difficult to learn mathematics so that they prefer doing other activities rather than paying attention (Kristiana \& Suyanto, 2013). Motivation is one of the factors that influence the effectiveness of learning. Motivation is an effort done consciously to take action, to learn, and to realize directed behavior to achieve the expected goals in learning interaction (Nurhasanah \& Sobandi, 2016). Motivation to learn plays a role in fostering a sense of pleasure and enthusiasm for learning (Setiawan, 2016). Motivation will move students to carry out learning activities. If students are motivated to carry out learning activities, it will have an impact on student learning outcomes. Student learning outcomes will be optimal if students are motivated to learn. That is, the existence of good motivation in learning will produce good learning outcomes. If students are more motivated to learn, then they tend to be involved and if they are involved, it is more likely for them to achieve learning goals (Kim \& Frick, 2011). Related to the process of learning mathematics, learning motivation needs to be instilled during learning, including growing strong impulses and learning needs, fostering attention and interest in mathematics, practicing perseverance in facing difficulties, and fostering desire to succeed (Lestari, 2014).

Student motivation is divided into two types, namely intrinsic and extrinsic motivation (Harandi, 2015). Students who are intrinsically motivated deeply involve themselves in learning from something unique, interesting, or fascinating to achieve their academic and personal goals. 
On the other hand, students who are extrinsically motivated are motivated due to external influences such as grades, gifts, rewards, status, ridicule, punishment, and so on. So students will try if there are stimuli from outside students. The intensity of student motivation will greatly determine the level of learning outcomes.

In the era of industrial revolution 4.0, information and technology are the main motors in the development of all aspects of life including education. These changes impact the nation's next generation. The millennial generation is already familiar with internet technology, specifically online games available on smartphones. The internet with all its sophistication brings both positive and negative impacts like a double-edged sword (Turel \& Osatuyi, 2017). Students only use smartphones to play online games that they like so that not a few parents who complain about their children are addicted to the smartphone. Thus, the education sector must be able to overcome the negative impacts of information and technology while optimizing the use of information technology media to improve the quality and effectiveness of learning. The advantage of using online technology is to eliminate limitations in learning so that learning can be done by anyone, anywhere, and anytime (Surjono et al, 2017). The benefits of learning media are to clarify the presentation of learning content while attracting the attention of students and improving learning motivation to impact the students' learning outcomes (Arsyad, 2014; Ningrum, 2018).

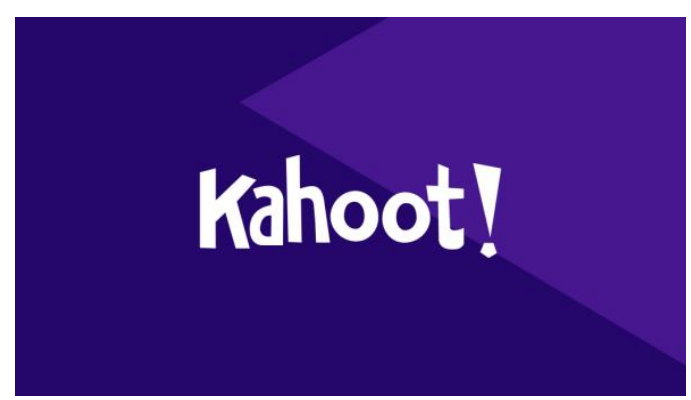

Figure 1. Kahoot Aplication Logo

One of the technological innovations to make learning more interesting for students is to use game-based learning. According to Hsieh et al, (2015) games can consistently increase students' involvement in a game-based learning environment which can provide insight as a good start. One of game-based learning is the Kahoot platform. Kahoot is an educational platform that was initiated by Johan Brand, Jamie Brooker, and Morten Versvik in 2013. To date, there are 20 million teachers and 2 billion students use Kahoot in more than 200 countries (Official Kahoot!, 2019). Kahoot has two different website addresses, https://Kahoot.com/ for teachers, and https://Kahoot.it/ for students. Kahoot can be accessed and used for free, including all the features in it. Kahoot Platform can be used for several forms of games including online quizzes, surveys, and discussions. There are also evaluations in the form of spreadsheets that can be downloaded on a computer or stored on Google drive.

Kahoot can be categorized as game-based learning which involves the active participation of students and is played in groups or individually with features in the form of quizzes, surveys, and discussions (Lai et al, 2014; Fitryanisa, 2019). Kahoot provides a quiz answering practice against the bot provided by the Kahoot app. Kahoot is available on Google Play store which can be downloaded by smartphone users for free so students can play Kahoot games outside of school. Kahoot also provides back sound music that can make students interested and not feel 
bored while doing the quizzes. Game-based learning involves the functions and principles of games in the classroom to involve student participation and improve the quality of learning (Graham, 2014; Dellos, 2015; Muhridza et al, 2018). Some relevant research shows that Kahoot can increase students' active participation (Barus \& Soedewo, 2014; Omar, 2017) and improve student learning outcomes (Ningrum, 2018). However, there is no research that combines the Kahoot application and game-based learning, so it is necessary to do research related to it.

The use of Kahoot media in learning requires at least good internet access, LCD projectors to display quiz questions, and computer equipment (laptops or smartphones). Learning using Kahoot media certainly cannot be implemented in every school because not all schools have sufficient facilities. Based on observations, SDN Wonosari I had enough units of computers in the laboratory for one class students. There was good internet access and had an LCD projector. So that SDN Wonosari I had fulfilled the requirements for learning with Kahoot media. The results of observations at SDN Wonosari showed that motivation to learn the mathematics of the fourth-grade students was low. Students were not eager to learn mathematics. They prefer to do other activities that have nothing to do with learning such as playing paper throwing, staring contests, playing around with their pen, and drawing. Also, they looked tense when the teacher told them to come to the front of the class to answer questions.

Based on the description, it is necessary to apply innovation in mathematics learning to increase student motivation in SDN I Wonosari, namely by utilizing Kahoot media in mathematics learning. This study aims to apply Kahoot media in mathematics learning to improve mathematics learning motivation of the fourth-grade elementary school students. This study can provide benefits by adding variations in the use of mathematics learning media so that it is expected to be able to solve one of the problems of education in Indonesia, especially the motivation to learn the mathematics of the elementary students.

\section{METHODS}

This study employed the Classroom Action Research (CAR). The model of study used was the one proposed by Kemmis \& MacTaggart. Each cycle consisted of the planning, action, observation, and reflection stages. The research planning phase was done by analyzing the core competences and basic competences of the syllabus, constructed the research instruments, prepared a lesson plan, and then prepared the learning media, namely the Kahoot quiz. The implementation phase was done by implementing the planning stage and implementing the learning activities using Kahoot. The observation phase was done by observing the process of learning activities. The reflection phase was done to reflect the implementation of the actions taken to improve the implementation of learning to achieve predetermined criteria. This study lasted for two learning cycles. The subjects of the study were 28 fourth-grade students of SDN Wonosari I in the second semester of the 2018/2019 academic year. 


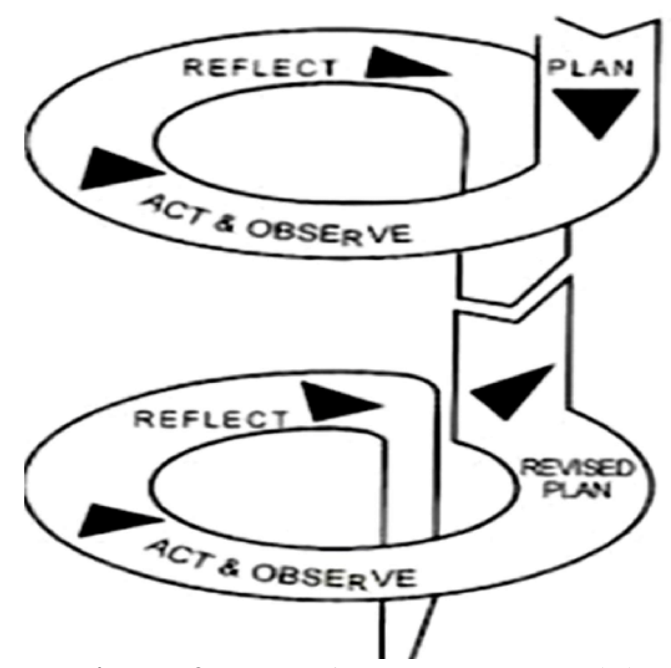

Figure 2. Kemmis \& Taggart Model

Data of the research was obtained using research instruments in the form of interview guidelines, observation sheets of learning activities, mathematics motivation questionnaires, and field notes. Interview guidelines were used to identify the initial level of motivation of students' mathematics learning. The observation sheet was used to observe the implementation of learning activities. The mathematics learning motivation questionnaires were used to measure mathematics learning motivation by distributing them to students after one learning cycle. Learning observation results were measured based on the criteria in Table 1.

Table 1. Criteria of Learning Implementation

\begin{tabular}{cc}
\hline Application $(a)$ & Criteria of Application \\
\hline $80 \%<a \leq 100 \%$ & Excellent \\
$60 \%<a \leq 80 \%$ & High \\
$40 \%<a \leq 60 \%$ & Moderate \\
$20 \%<a \leq 40 \%$ & Low \\
$0 \% \leq a \leq 100 \%$ & Poor \\
\hline
\end{tabular}

The implementation of learning with Kahoot can be said as excellent if the implementation of the learning reaches $\geq 81 \%$.

The results of the mathematics learning motivation questionnaire were used to measure the level of students' motivation in learning mathematics. The results of the mathematics learning motivation questionnaire were analyzed and converted into poor, low, medium, high, and excellent categories. The questionnaire data were converted using a formula. The conversion table can be seen in Table 2 .

Table 2. Conversion Score Category

\begin{tabular}{cc}
\hline Interval Score $(x)$ & Category \\
\hline$x>63$ & Excellent \\
$51<x \leq 63$ & High \\
$39<x \leq 51$ & Moderate \\
$27<x \leq 39$ & Low \\
$x \leq 27$ & Poor \\
\hline
\end{tabular}

The success of action was measured through the student motivation questionnaires. The action is said to be successful if the student's motivation is in the high category. 


\section{RESULTS AND DISCUSSION}

The implementation of the first cycle began on March 25, 2019 (first meeting), and continued to the second meeting on March 26, 2019. The planning stage was done by analyzing the core competencies and basic competencies of mathematics learning in the fourth-grade of elementary school, constructed a lesson plan (RPP), and prepared to learn media namely the Kahoot quiz.

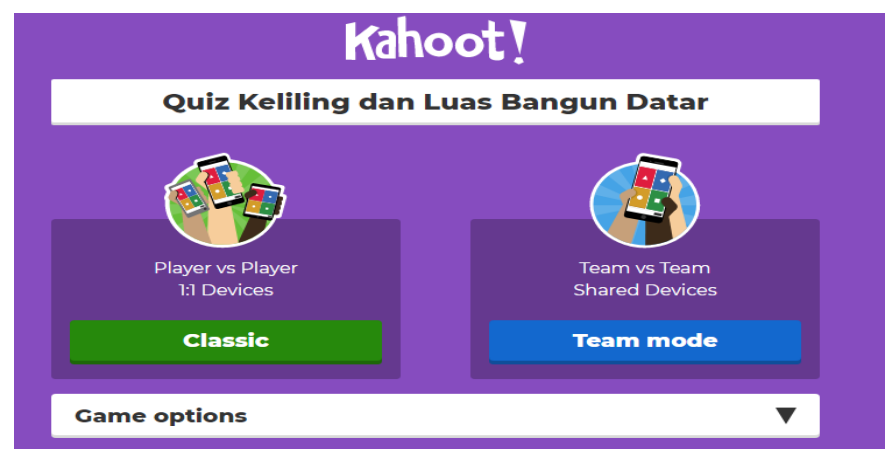

Figure 3. Display of the Quiz Mode

The learning implementation phase began with a preliminary activity that aimed to convey the learning objectives and develop initial knowledge that might or might not be owned by students through apperception activities. At the core activity, the teacher started the learning by using Kahoot media by opening the page and connecting the projector LCD. In using the Kahoot app, the teacher acted as the organizer of the quiz (quiz host) by accessing https://Kahoot.com/ then selected the Kahoot to be used and chose the game mode. There were two game modes, namely classic mode and team mode. Classic mode is an individual quiz game where each student could be a quiz participant and competes with other participants while the team mode is a group quiz game where students can work together to competitively answer the quiz.

When the teacher hosted the quiz, a pin code appeared which then inputted by the students to enter the quiz game. When all participants had been registered in the game, the teacher started the Kahoot Quiz. The students answered by pressing the selection button as can be seen on the projector screen. In the team mode, students can discuss to determine which answer is the most appropriate, however, it must be done quickly because there are time constraints on the questions.

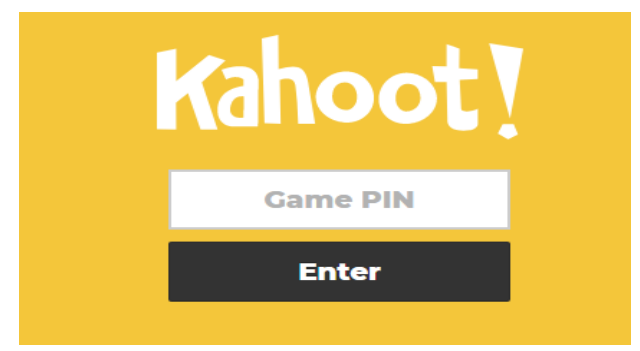

Figure 4. Kahoot Game Pin

The students were asked to open the page http://kahot.it/ and entered the pin based on the teacher's direction. Then students tried to answer multiple-choice and true and false questions.

The observation stage was carried out by the observer to observe the implementation of learning with Kahoot. The observers observed the learning and filled in observation sheets to assess the learning. The reflection phase was done after the school class ended in the learning cycle I. it was suggested to pay more attention to the class organization and the allocation of 
learning time. Also, a more detailed explanation was needed when logging in to enter the pin code because some students had difficulty and caused the allocation of learning time was not according to the plan.

The results of observations of learning in the first cycle showed that the use of Kahoot was considered quite well. Observers pointed out several important activities that were missing, such as providing a follow-up explanation after learning. The class atmosphere was quite crowded because the students were enthusiastic so that the class needed to be better conditioned. Below is the table learning outcomes in the first cycle.

Table 3. The Implementation of Learning cycle I

\begin{tabular}{lcc}
\hline \multicolumn{1}{c}{ Cycle I } & Percentage of Learning Achievement (\%) & Criteria \\
\hline First meeting & 69.7 & Good \\
Second meeting & 75.8 & Good \\
Average & 72.3 & Good \\
\hline
\end{tabular}

Based on table 3, the feasibility of learning using Kahoot is included in the good category. The result did not meet the established excellent criteria, which is $\geq 81 \%$.

Students' mathematics learning motivation was measured through a mathematics learning motivation questionnaire. The mathematics learning motivation questionnaire was given after the students had finished the learning cycle I. Here are the results of the mathematics learning motivation questionnaire of students in cycle I.

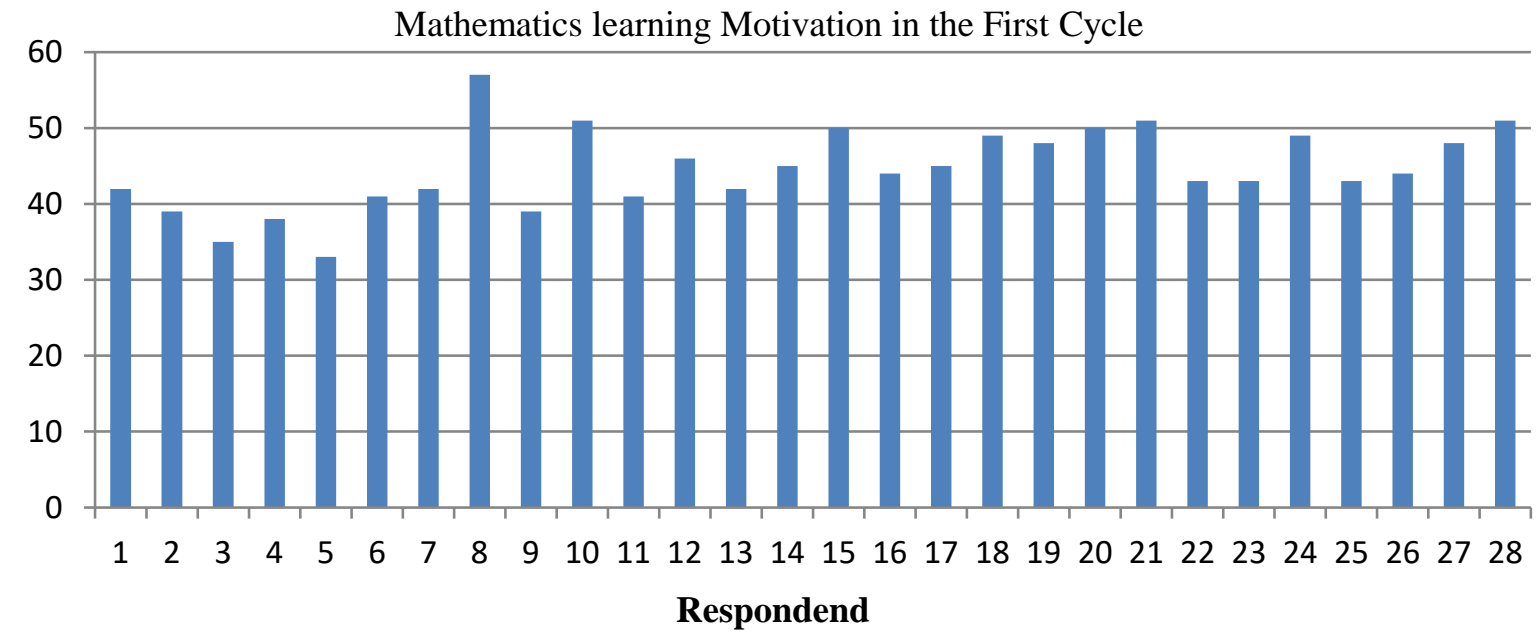

Figure 5. The Results of Learning Motivation Questionnaire I

Based on figure 5, the average students' learning motivation was 44.32 which is included in the medium category. This result had not reached the criteria for completeness of the predetermined criteria, namely the high category. Thus, there was a need for improvement in learning in the next cycle.

The implementation of the action in cycle II was carried out on April 1, 2019, and continued at the second meeting on April 2, 2019. The cycle II learning process had the same procedure as the learning cycle I, but in the learning cycle II had made some improvements. The improvements made in the second cycle, namely made the questions more varied, gave more accurate answer time based on the level of difficulty of the questions, managed the students' seating positions in advance according to the number of groups so that learning took 
place more efficiently, and the allocation of discussion time was arranged to be more efficient.

Based on the observations of the implementation of the learning cycle II, it can be concluded that the second cycle had been carried out with excellent criteria. The results of the average percentage of the implementation of the second cycle had met the criteria of success, namely the results of the analysis of the feasibility of learning using Kahoot media which reached a percentage of $\geq 81 \%$ mentation. The percentage of the implementation of learning cycle II can be seen in table 4 .

Table 4. Learning Cycle II

\begin{tabular}{lcc}
\hline \multicolumn{1}{c}{ Cycle I } & Percentage of Learning Achievement (\%) & Criteria \\
\hline First meeting & 84.8 & Excellent \\
Second meeting & 93.9 & Excellent \\
Average & 89.35 & Excellent \\
\hline
\end{tabular}

Student mathematics learning motivation was measured through a mathematics learning motivation questionnaire. The questionnaires were given after students had finished one learning in cycle II. The following are the results of students' mathematics learning motivation questionnaire in cycle II.

Mathematics learning Motivation in the Second Cycle

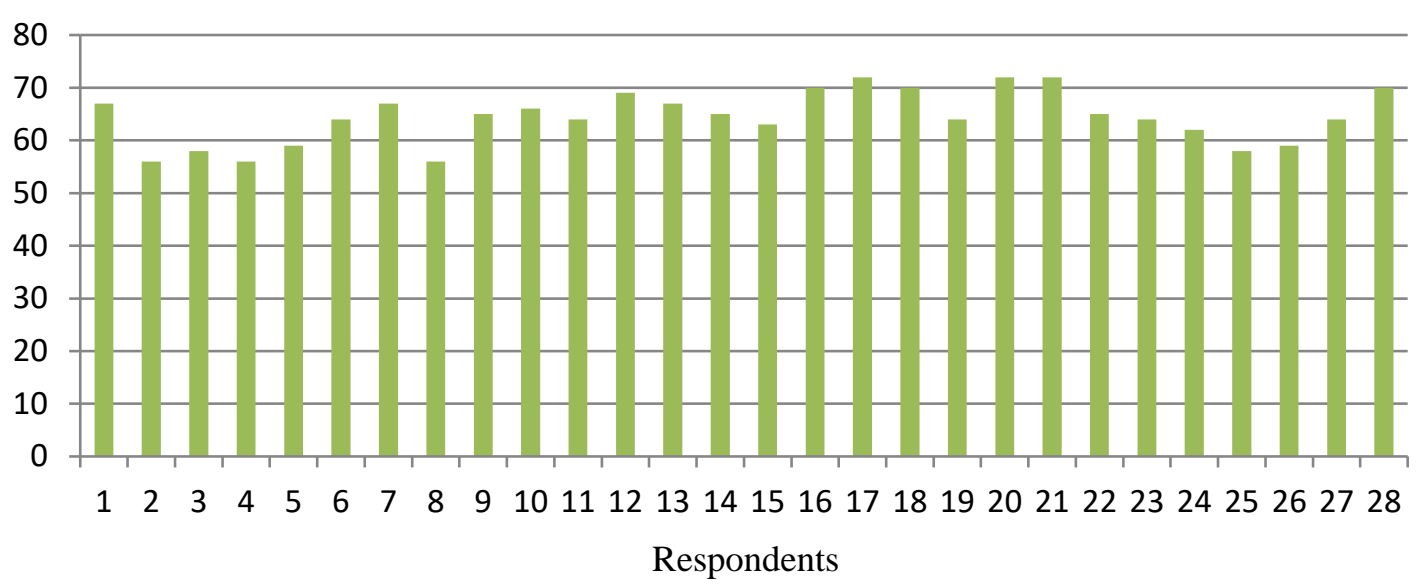

Figure 6. The Results of the Learning Motivation Questionnaire in the Second Cycle

In the graph above, the results of the first cycle of learning motivation questionnaire show the average student motivation is 64.42 with a very high category. The results of the second cycle of learning motivation questionnaires have reached the criteria for completeness of the predetermined actions, namely in the high minimum category. When compared with the results of the first cycle, an average increase of 19.85 points or $44.55 \%$.

The implementation of mathematics learning using Kahoot media can increase motivation to learn mathematics in students. Students in learning try to work on Kahoot quiz questions and compete with other groups. This is what motivates students to learn mathematics because they do not want to lose to other group friends. These results are in line with research by Barus \& Soedewo (2014) which states that learning with Kahoot media helps students to recall given material, makes them more excited, happy, not bored and can actively participate. The application of interactive quiz media based on Kahoot educational games can accelerate students' understanding of the material that has been taught because it provides direct feedback (Ningrum, 2018). Students can be more willing to express their opinions on material that they 
feel has less understanding. In line with research game-based learning has a positive effect on student motivation.

Based on the results of the study there was an increase in students' motivation in cycle I to cycle II. The improvement of learning motivation can be seen in Figure 7.

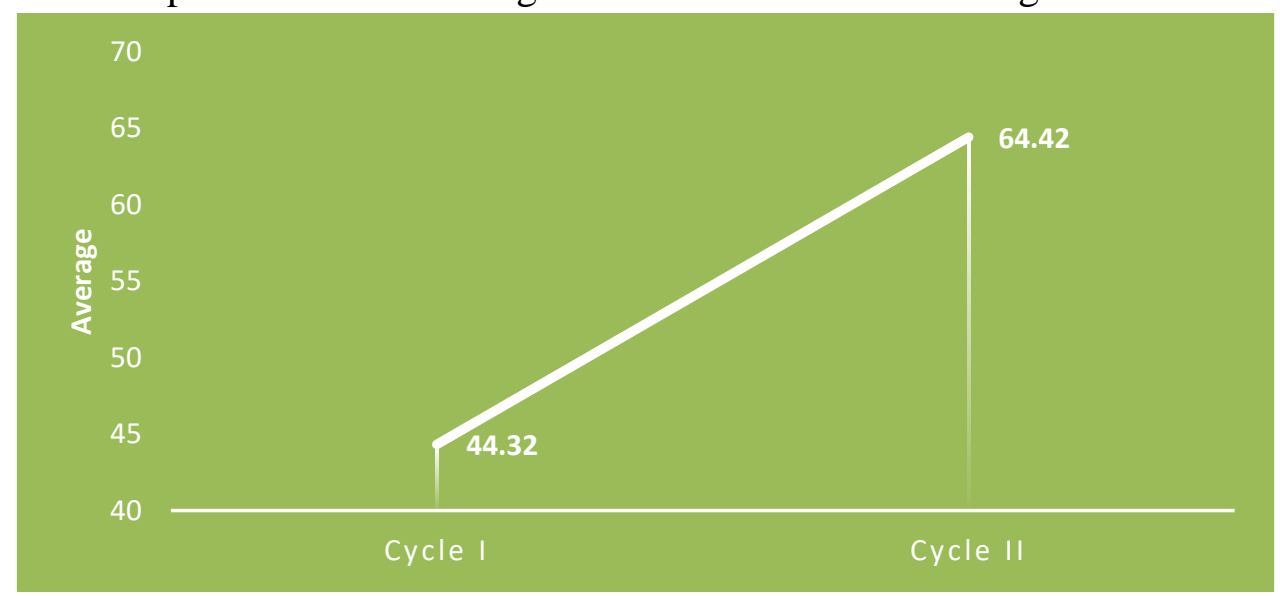

Figure 7. Improvement of Student Learning Motivation

In the aspect of fostering a strong drive and learning needs, Kahoot works as a stimulus for internal and external motivation. After learning through Kahoot, the students were interested in learning mathematics and their numeracy speed increased so they don't lose fast when answering questions. Kahoot creates a conducive, competitive, and collaborative learning environment (Leung \& Pluskwik, 2018; Turan \& Meral, 2018). In the aspect of fostering attention and interest in mathematics, kahoot makes it easy for students to learn mathematics more concretely because the questions are given illustrations that are easily understood by students. At the Piaget development stage, the fourth-graders are at the concrete operational stage. In the aspect of practicing perseverance in the face of difficulties, kahoot provides exercises that can be repeated by students whenever and wherever they are. This is relevant to the principles of online learning proposed by Surjono et al (2017) that online learning technology eliminates limitations in learning so learning can be done by anyone, anywhere, and anytime. In the aspect of fostering a desire to succeed, students are interested in Kahoot which they think is something new and challenging to try. Like a game that can make players thirsty for victory, Kahoot also triggers students to compete with their friends so that it grows on students' desire to succeed and becoming champions (Leung \& Pluskwik, 2018). Kahoot also succeeded in triggering "healthy" competition in the classroom. The students were motivated to become champions as their names are displayed on the monitor screen, so students paid more attention during the learning process (Licorish et al, 2017).

In Cycle II, students were accustomed to using Kahoot. In cycle I, students was not accustomed to using Kahoot so it might make them less interested. After getting better guidance on learning cycle II, students became interested and motivated to learn and tried to compete with their peers. Kahoot also emphasized aspects of visualization, music, and the atmosphere of competition so that it could attract students' attention (Muhridza et al, 2018). Learning with Kahoot makes learning more fun, more meaningful, and serves as a valuable experience for students (Siegle, 2015).

In the second cycle, some Kahoot questions were made to be more varied than the questions in the first cycle of learning. The type of questions given in the first cycle learning 
were multiple-choice questions while in the second cycle, there were true or false questions. The addition of the types of questions made the students challenged to try to answer the questions. Also, the time allocation in answering was set according to the level of difficulty of the questions, so the average time needed for students to answer one question was 1 minute. This change made the students more focused and challenged to answer the questions.

\section{CONCLUSIONS}

Based on the results and discussion, it can be concluded that Kahoot can increase the motivation to learn the mathematics of the fourth-grade students of SD N Wonosari I. There was an increase in motivation to learn mathematics by 44.32 in cycle I to 64.42 in cycle II. The students' motivation from cycle I to cycle II increased by 19.85 or $44.55 \%$.

The implementation of Kahoot media in mathematics learning faced several obstacles. During the second meeting of the first cycle, the internet connection was interrupted which caused learning to stop for a moment to wait for students to reconnect to the game. It would be better if Kahoot is applied at schools that do not prohibit students from having cellphones/ Smartphones so that the technical risks such as disconnected Wi-Fi can be resolved by replacing substandard school Wi-Fi with cell phone internet connections even though it will cost the students. There is a need for thorough technical preparation such as a smooth internet network and good computer equipment if you want to use Kahoot as a medium. Nevertheless, the benefits of Kahoot, especially in mathematics learning, can increase mathematics learning motivation. Kahoot mathematics learning media used in this study is limited to circumference and the width two-dimensional figures. It is strongly recommended for further research to research other materials with a broader scope of fields.

\section{AUTHOR CONTRIBUTIONS STATEMENT}

AS and SS worked as the main drafter in this study. They assists the implementation and design of research articles.

\section{REFERENCES}

Arsyad, A. (2014). Media Pembelajaran. Jakarta: PT Raja Grafindo Persada.

Barus, I. R. G., \& Soedewo, T. (2014). Penggunaan media kahoot! dalam pembelajaran struktur bahasa inggris. In Seminar Nasional Teknologi Terapan Berbasis Kearifan Lokal (pp. 589-596).

Dellos, R. (2015). Kahoot! A digital game resource for learning. International Journal of Instructional Technology and Distance Learning, 12(4), 49-52.

Fitryanisa, S. M. A. (2019). Media pembelajaran kahoot dalam pembelajaran bahasa arab di UIN maulana. In Seminar Nasional Bahasa Arab Mahasiswa III UNM (pp. 19-37).

Graham, K. (2014). TechMatters : Getting into kahoot!(s): exploring a game - based learning system to enhance student learning. Loex Quarterly, 42, 6-7.

Harandi, S. R. (2015). Effects of e-learning on students' motivation. Procedia - Social and Behavioral Sciences, 181, 423-430.

Hsieh, Y., Lin, Y., \& Hou, H. (2015). Exploring elementary-school students' engagement patterns in a game-based learning environment. Journal of Educational Technology \& 
Society, 18(2), 336-348.

Kim, K., \& Frick, T. W. (2011). Changes in student motivation during online learning. Journal Educational Computing Research, 44(1), 1-23.

Kristiana, D., \& Suyanto, W. (2013). Implementasi heuristic problem solving dalam menyelesaikan soal cerita untuk meningkatkan prestasi dan sikap matematika. Jurnal Prima Edukasia, 1(1), 17-29.

Lai, C., Lin, Y., Jong, B., \& Hsia, Y. (2014). Adding social elements to game-based learning. iJET, 9(3), 12-15.

Lestari, K. E. (2014). Implementasi brain-based learning untuk meningkatkan kemampuan koneksi dan kemampuan berpikir kritis serta motivasi belajar siswa SMP. Jurnal Pendidikan UNSIKA, 2(1), 36-46.

Leung, E., \& Pluskwik, E. (2018). Effectiveness of gamification activities in a project-based learning class- room effectiveness of gamification activities in a project-based learning classroom. In ASEE Annual Conference \& Exposition.

Licorish, S. A., Owen, H., \& Daniel, B. K. (2017). “ Go Kahoot!” Enriching classroom engagement, motivation and learning experience with games. In Proceedings of the 25th International Conference on Computers in Education (pp. 755-764).

Muhridza, N. H. M., Rosli, N. A. M., Sirri, A., \& Samad, A. A. (2018). Using game-based technology, kahoot! for classroom engagement. LSP International Journal, 5(2), 37-48.

Ningrum, G. D. K. (2018). Studi penerapan media kuis interaktif berbasis game edukasi kahoot! terhadap hasil belajar mahasiswa. Vox Edukasi, 9(1), 22-27.

Nurhasanah, S., \& Sobandi, A. (2016). Minat belajar sebagai determinan hasil belajar siswa. Jurnal Pendidikan Manajemen Perkantoran, 1(1), 128-135.

Omar, N. N. (2017). The efffectiveness of kahoot application towards students' good feedback practice. PEOPLE: International Journal of Social Sciences, 3(2), 2551-2562.

Setiawan, A. (2016). Hubungan kausal penalaran matematis terhadap prestasi belajar matematika pada materi bangun ruang sisi datar ditinjau dari motivasi belajar matematika siswa. Al-Jabar: Jurnal Pendidikan Matematika, 7(1), 91-100.

Siegle, D. (2015). Technology learning can be fun and games. Gifted Child Today, 38(3), 192197.

Surjono, H. D., Muhtadi, A., \& Wahyuningsih, D. (2017). The implementation of blended learning in multimedia courses for undergraduate students in Indonesia. International Journal of Infomation and Education Technology, 7(10), 783-786.

Turan, Z., \& Meral, E. (2018). Game-based versus to non-game-based: the impact of student response systems on students' achievements, engagements and test anxieties. Informatics in Education, 17(1), 105-116.

Turel, O., \& Osatuyi, B. (2017). A peer-influence perspective on compulsive social networking site use: Trait mindfulness as a double-edged. Computers in Human Behavior, 77, 47-53. 